\title{
Developing a Water Management Model for Esfahan Metropolis within the Framework of Green City Approach
}

Jamal Mohammadi ${ }^{1}$

Abolfazle Masoudian²

\section{Mohammadreza Kanani $3^{*}$}

\author{
${ }^{1}$ Associate Professor of Geography and Urban Planning, University of Esfahan, Esfahan, Iran \\ ${ }^{2}$ Professor of Geography and Urban Planning, University of Esfahan, Esfahan, Iran \\ ${ }^{3}$ Phd Student in Geography and Urban Planning, University of Esfahan, Esfahan, Iran
}

Doi:10.5901/mjss.2015.v6n6s2p532

\section{Abstract}

\begin{abstract}
Esfahan metropolis is faced with several environmental problems. Hence, the present research was an attempt to propose strategies for optimal management of Esfahan Metropolis by studying the stresses on the water of this metropolitan city. In this study, the environmental condition of Esfahan metropolis was examined within the framework of the green city approach using a combination of the PSR and MCDM models. Afterwards, the strategies were formulated using the IFE, EFE, SWOT, IE, and QSPM matrices. Research results revealed that the status of the water component of Esfahan Metropolis is not desirable with regard to the green city approach. That is to say, in the study period, from 2008 to 2009 conditions in the city showed the highest (0.53) and lowest (0.35) similarity to the ideal solution, respectively. Therefore, in order to attain the water-related goals of the Esfahan green city approach it is necessary to adopt defensive strategies.
\end{abstract}

Keywords: Green City, Water Management, Esfahan Metropolis

\section{Introduction}

With the beginning of the twentieth century, and parallel to a series of technological developments which led to the development of new production and industrial processes, the scope and depth of environmental issues escalated. Therefore, sustainable development was born and developed close to the transition from the twentieth century to the twenty-first century (Bahramsultani, 2008). This form of development is currently accepted as the dominant development model by the world (Liu et. al., 2014; Abu Bakar \& Cheen, 2013; Yalcin, 2014; Dempsey et. al., 2012; Song, 2011). In recent years, the green city approach, which is related to the sustainability of urban environment, has been introduced following the theory of sustainable development. As the essence of sustainable urban development it emphasizes the concern for the urban environment and protecting it with our responsibilities towards current and future generations of mankind (Cohen \& Ronnins, 2011; Kahn, 2006; Abdul Latif et. al., 2013; Turner, 2008; Wu, 2009; Featherstone et. al., 2011). In fact, the green city approach with a focus on theoretical and practical aspects of sustainable development, suggests why and how we should have green cities. Moreover, the priority of green cities is paying attention to the requisite that urban development shall not cause the destruction of environmental systems in a way that residents of urban areas and future generations are not able to meet their needs. In addition, imposing environmental costs of producers and consumers on others or other ecosystems should be prevented (Pugh, 2004).

A review of the research literature shows that with the universal adoption of the green city approach, practical measures such as the following have been taken to attain the green city goals: strategic development program for the metropolitan area of Sydney (2005), strategic development program of city of Warsaw (2005), strategic program of green city of Pasadena (2006), Sydney strategic development program (2008), European green city index (2009), Latin American green city Indices (2010), indices of green city of Pasadena (2010), Asian green city index (2011), America and Canada green city index (2011), and African green city index (2011). However, no measures have been taken for evaluating the status of urban settlements using green city indices, and developing a strategic program to achieve green city goals in Iran. Therefore, the present study aimed to investigate the qualitative and quantitative status of water in metropolitan city of Isfahan within the framework of the green city approach and to propose strategies for attaining the water-related green city goals of Isfahan Metropolis. 


\section{Material and Method}

The present study is considered an applied research in terms of purpose, and a descriptive-analytical study in terms of its nature and method. Spatiotemporal range of the study includes the Esfahan Metropolis from 2008 to 2012. Esfahan Metropolis is the capital of Esfahan province with an area of 482 square kilometers $(0.03 \%$ of the total area of the country) in a semi-arid region in central Iran. It lies along the Zayandeh-Rood river which has a longitude of $51^{\circ} 41^{\prime \prime}-51^{\circ} 50^{\prime \prime} E$ and latitude of $32^{\circ} 32^{\prime \prime}-32^{\circ} 51^{\prime \prime} N$ (Fig. 1). According to the General Census of Population and Housing in 2011, metropolitan city of Esfahan has a population of 1,796,967 people, and is considered the third largest metropolitan city of Iran after Tehran and Mashhad.

The Fuzzy Delphi method (Kaufman \& Gupta, 1988) was used in this study to determine the water-related green city indices. Hence, in the first phase each member of the expert group (which included 32 experts in the field of urban environment) was given a questionnaire separately consisting of indices resulted from reviewing the literature. The respondents were asked to submit their proposals based on their experiences, and scientific knowledge. Next, the viewpoints of the expert group were gathered and summarized, and were returned to the group members once again for the purpose of any probable regulation, correction, and revision. This trend continued to the extent that in the third phase a general consensus was obtained with regard to the water-related green city indices. Next, values of the aforementioned indices during the study period were collected by using the secondary research method and field work results. Unfortunately, in this process, some of the indices inevitably were excluded from the study due to the lack of cooperation in providing data and information by the relevant principles. It is worth mentioning that for investigating the quality status of surface and subsurface water of Esfahan Metropolis, the Water Quality Index (National Sanitation Foundation, 1970) and World Health Organization standards $(\mathrm{WHO}, 2011)$ were used respectively. Examination of the status of water in Esfahan Metropolis was performed by utilizing a combination of the framework of PSR with MCDM (Dal et al., 2010; BAI\& TANG; 2010). The framework of PSR (OECD, 1994) which has been widely considered in order to describe the environmental status (Hughey et al., 2004; Zhang et al., 2012; Wang et al., 2013; SANUSI, 2011), made it possible for the researchers to categorize the indices that were influential on water of metropolitan city of Esfahan. Results indicate a causal relationship with regard to the environmental status of water in the metropolitan city of Esfahan. Next, examination of the environmental status of water in metropolitan city of Esfahan during the study period was carried out through using the integrated Entropy-TOPSIS method (Hwang \& Yoon, 1981; Jozi et. al., 2012; Li et. al, 2012; Guo et. al., 2008) (Fig. 2).

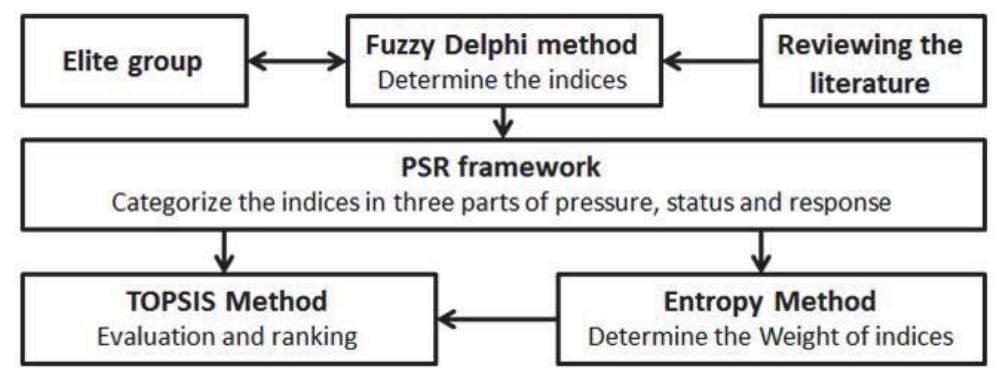

Figure 2. Framework of PSR with MCDM

Development of strategies to achieve the water-related green city goals of Esfahan was carried within a comprehensive framework (Shiehbeiki et. al., 2014; Tehrani et. al., 2010; Navabakhsh \& Tavakolan, 2013; Yavuz \& Baycan, 2013). Hence, the key internal (strengths and weaknesses) and external (opportunities and threats) factors were identified based on the viewpoints of 400 residents and by using a questionnaire. Results were evaluated and prioritized based on internal factors evaluation matrix and external factors evaluation matrix as well as expert opinions. Afterwards, by using the SWOT matrix and output of the Delphi group, internal and external factors were compared, and strategies to achieve the water-related green city goals of Esfahan were proposed based on the following four classifications: aggressive strategies, conservation strategies, diversification strategies and defensive strategies. The focus of each strategy was also shown using an internal and external matrix. In the end, through quantitative planning matrix as well as the participation of experts in the field of urban environment, the relative attractiveness of strategies was determined, and the 
top strategies were identified(Fig. 3).

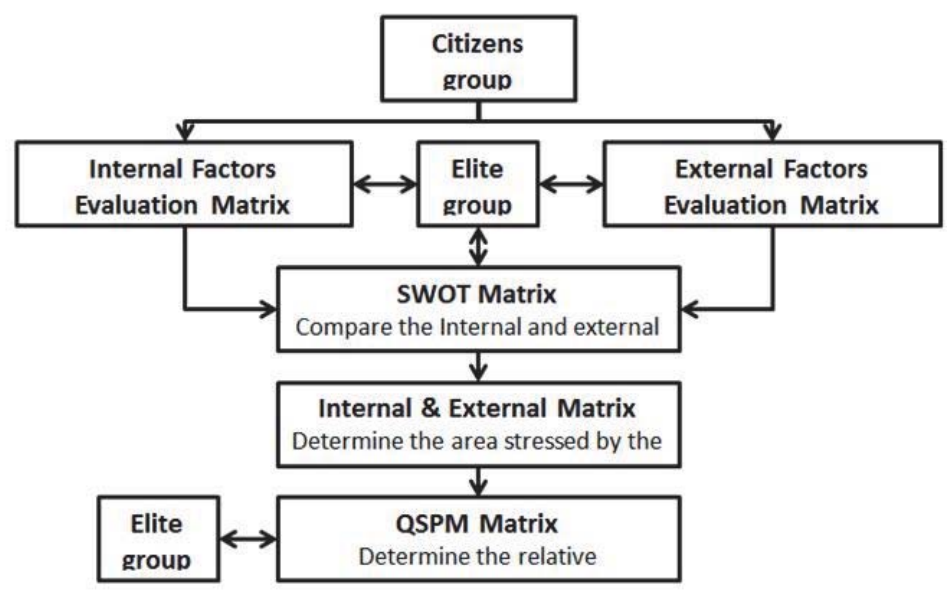

Figure 3. Framework of development strategies

\section{Result and Discussion}

The water-related green city indices from reviewing the literature and using the Delphi method include 33 indices in 19 groups in three areas of pressure, status, and response (Table 1). The absolute height index of the groundwater level in Borkhar plain has the highest degree of relative importance $(0.03)$ whereas environmental monitoring index in the urban peripherals has the lowest degree of relative importance (0.02). Moreover, indices of the absolute height of the groundwater level in Sagsi Plain, length of water transmission lines, length of drinking water transmission line, drinking water consumption rate (which follow the index of absolute height of the groundwater level in Borkhar plain) have the highest degree of relative importance, respectively. Indices of units in Amirkabir Technology Plant City, optimization of industrial sewage treatment systems, the foresting area, therate of cleaning materials streams (which follow environmental monitoring index of units in urban peripherals)have also the lowest degree of relative importance, respectively (Table 2).

Table 1. Influential factors and indices in water component of metropolitan city of Esfahan within the framework of the green city approach

\begin{tabular}{|c|c|c|}
\hline \multicolumn{2}{|c|}{ Group of indices } & Indices \\
\hline \multirow{5}{*}{ 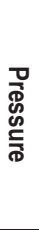 } & Water consumption & $\begin{array}{l}\text { The amount of supply of drinking water from surface and subsurface water resources; } \\
\text { Drinking water consumption rate }\end{array}$ \\
\hline & Water loss & The rate of drinking water loss in the distribution network; \\
\hline & Urban sewage & The rate of urban sewage collection \\
\hline & Industrial sewage & $\begin{array}{l}\text { The number of industrial units located in industrial estates; The number of industrial units } \\
\text { scattered in vicinity of city }\end{array}$ \\
\hline & Agricultural sewage & The intake rate of herbal pesticides; The consumption rate of fertilizers \\
\hline \multirow{2}{*}{$\frac{\mathscr{C}}{\stackrel{\vec{D}}{\Phi}}$} & Water quantity & $\begin{array}{l}\text { The average water flow of Zayandeh-rood river; The average absolute height of } \\
\text { groundwater level of Segsi and Borkhar plains }\end{array}$ \\
\hline & Water quality & $\begin{array}{l}\text { The status of WQI index in Zayandeh-rood river water; The status of WHO standard in } \\
\text { subsurface waters of Borkhar and Segsi plains }\end{array}$ \\
\hline \multirow{3}{*}{ 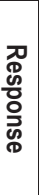 } & Desertification & $\begin{array}{l}\text { The area of seedling plantation; The area of seeding and seeding plantation; The area of } \\
\text { forestation }\end{array}$ \\
\hline & $\begin{array}{l}\text { The development and improvement of } \\
\text { water distribution network }\end{array}$ & $\begin{array}{l}\text { The length of drinking water transmission line; The length of drinking water distribution } \\
\text { network; The number of branches of drinking water }\end{array}$ \\
\hline & Organizing streams & $\begin{array}{l}\text { The cleaning rate of streams; The dredging rate of streams; The body making rate of } \\
\text { streams }\end{array}$ \\
\hline
\end{tabular}




\begin{tabular}{|l|l|l|}
\hline Urban sewage management & $\begin{array}{l}\text { The number of urban sewage split; The length of urban sewage collection network; The } \\
\text { length of urban sewage transmission lines; The rate of urban sewage treatment; }\end{array}$ \\
\hline Industrial sewage management & $\begin{array}{l}\text { The number of constructions of industrial sewage treatment systems; The number of } \\
\text { optimization of industrial sewage treatment system }\end{array}$ \\
\hline Organizing annoying jobs & The number of organizing annoying jobs \\
\hline Agriculture sewage management & The rate of biological pest control \\
\hline Environmental Monitoring & $\begin{array}{l}\text { The number of trusted laboratories with water section; The number of sampling from } \\
\text { Zayandeh-rood river; The environmental monitoring of units located on the boundary }\end{array}$ \\
\hline
\end{tabular}

Table 2. The relative priority of influential indices in water component of metropolitan city of Esfahan within the framework of the green city approach.

\begin{tabular}{|l|c|}
\hline Indices & Weight \\
\hline The average absolute height of groundwater level of Borkhar plains & 0.031837607 \\
\hline The average absolute height of groundwater level of Segsi plains & 0.031837606 \\
\hline The length of drinking water transmission line & 0.031837518 \\
\hline The length of urban sewage collection network & 0.031836512 \\
\hline Drinking water consumption rate & 0.031836175 \\
\hline The intake rate of herbal pesticides & 0.031835778 \\
\hline The length of drinking water distribution network & 0.031835590 \\
\hline The length of urban sewage collection network & 0.031835404 \\
\hline The number of urban sewage split & 0.031831654 \\
\hline The number of units located in industrial estates & 0.031830118 \\
\hline The status of WQI index in Zayandeh-rood river & 0.031828577 \\
\hline The number of industrial units scattered in vicinity & 0.031826305 \\
\hline The amount of supply of drinking water from surface and subsurface water resources & 0.031814259 \\
\hline The rate of urban sewage treatment & 0.031812698 \\
\hline The rate of urban sewage collection & 0.031812698 \\
\hline The rate of drinking water loss in the distribution network & 0.031669980 \\
\hline The consumption rate of fertilizers & 0.031661800 \\
\hline The number of constructions of industrial sewage treatment systems & 0.031624161 \\
\hline The number of sampling from Zayandeh-rood rive & 0.031558577 \\
\hline The amount of supply of drinking water from surface and subsurface water resources & 0.031374904 \\
\hline The number of trusted laboratories with water & 0.030488075 \\
\hline The body making rate of streams & 0.030039170 \\
\hline The rate of biological pest control & 0.029974408 \\
\hline The average water flow of Zayandeh-rood river & 0.029287017 \\
\hline The number of branches of drinking water & 0.028609971 \\
\hline The area of seedling plantation & 0.028448466 \\
\hline The area of seeding and seeding plantation & 0.028364337 \\
\hline The dredging rate of streams & 0.028028782 \\
\hline The cleaning rate of streams & 0.027994840 \\
\hline The area of forestation & 0.026699190 \\
\hline The number of optimization of industrial sewage treatment system & 0.025697747 \\
\hline The number of organizing annoying jobs & 0.025652477 \\
\hline Environmental Monitoring & 0.025377585 \\
\hline & \\
\hline
\end{tabular}

Assessment and ranking of the indices influencing the water component of the metropolitan city of Esfahan using the ranking model which was based on similarity to the ideal extent suggests that the status of water component of the metropolitan city of Esfahan from 2008 and 2009 had the highest (0.53) and the lowest $(0.35)$ relative closeness to the ideal solution respectively. These figures show the best and worst environmental conditions in the city (Fig. 4). 


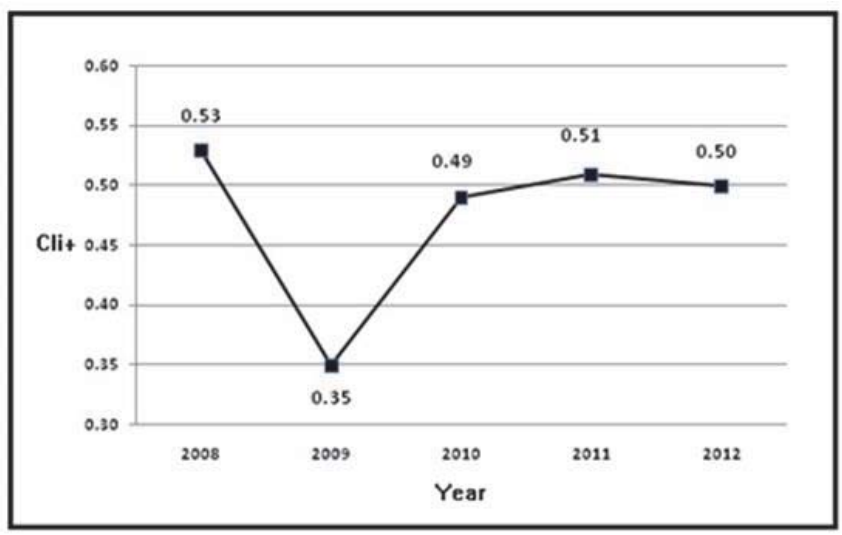

Figure 4. The status of water component of metropolitan city of Esfahan within the framework of the green city approach over the period 2008 to 2012

The results obtained from the identifying internal and external factors influencing the water component of the metropolitan city of Esfahan using the citizens and the evaluation resulted from internal factors evaluation matrix and external factors evaluation matrix using the Delphi group suggest that among other internal factors the extensive network of materials and streams (with a final score of 0.48) is the most important strength. Moreover, aqueducts drying in urban peripherals and the establishment of industrial cities and small industrial plants (with a final score of 0.1) in those areas were identified as the main weaknesses (Table 3). Regarding the external factors, Zayandeh-Rood River (with a final score of 0.6) bears the city's highest priority and opportunity. In this regard, rapid physical development of the city with a final score of 0.2 is considered to be the most important threat (Table 4). It should be noted that the total final scores for both internal and external factors are 1.89 and 1.94, respectively. This indicates the dominance of the strengths over weaknesses for internal factors and opportunities over threats for external factors.

Table 3. Internal Factors Evaluation Matrix

\begin{tabular}{|c|c|c|c|c|}
\hline \multicolumn{2}{|c|}{ Factors } & Weight & Grade & Score \\
\hline 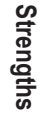 & $\begin{array}{l}\mathbf{S}_{1} \text { :Wide area network of streams in Esfahan city } \\
\mathbf{S}_{2} \text { :Sewage treatment plants in North, South and East of the city of Esfahan } \\
\mathbf{S}_{3} \text { :The plantation of drought tolerant plant species }\end{array}$ & $\begin{array}{l}0.12 \\
0.06 \\
0.04\end{array}$ & $\begin{array}{l}4 \\
3 \\
3\end{array}$ & $\begin{array}{l}0.48 \\
0.18 \\
0.12\end{array}$ \\
\hline 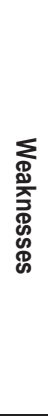 & $\begin{array}{l}\mathbf{W}_{1} \text { :The indiscriminate harvesting of Zayandeh-rood river water } \\
\mathbf{W}_{2} \text { : Drying of aqueducts in the boundary of Esfahan city } \\
\mathbf{W}_{3} \text { :High level of per capita water use in the city of Esfahan } \\
\mathbf{W}_{4} \text { : Old drinking water distribution network of the city of Esfahan in some areas of the city } \\
\mathbf{W}_{5} \text { :Indiscriminate harvesting of water from deep and half-deep wells in the vicinity of Esfahan } \\
\mathbf{W}_{6} \text { : The increase in impervious surfaces in the vicinity of Esfahan } \\
\mathbf{W}_{7} \text { :Traditional irrigation of green space in some areas of the city of Esfahan } \\
\mathbf{W}_{8} \text { :Old sewage collection network and sewage treatment facility in the south } \\
\mathbf{W}_{9} \text { : Inaccurate zoning of urban areas } \\
\mathbf{W}_{10} \text { :The establishment of incompatible activities in Zayandeh-rood river bed and boundary } \\
\mathbf{W}_{11} \text { :The lack of or defect in the sewage treatment system of the industries located } \\
\mathbf{W}_{12} \text { :The indiscriminate use of pesticides and chemical fertilizers } \\
\mathbf{W}_{13} \text { :The establishment of industrial estates and small workshop industries in the city boundary }\end{array}$ & $\begin{array}{l}0.08 \\
0.1 \\
0.09 \\
0.06 \\
0.08 \\
0.04 \\
0.04 \\
0.06 \\
0.05 \\
0.05 \\
0.04 \\
0.04 \\
0.05\end{array}$ & $\begin{array}{l}1 \\
1 \\
1 \\
2 \\
2 \\
2 \\
2 \\
2 \\
1 \\
1 \\
1 \\
1 \\
2 \\
\end{array}$ & $\begin{array}{c}0.08 \\
0.1 \\
0.09 \\
0.12 \\
0.16 \\
0.08 \\
0.08 \\
0.12 \\
0.05 \\
0.05 \\
0.04 \\
0.04 \\
0.1 \\
\end{array}$ \\
\hline \multicolumn{2}{|c|}{ Total } & 1 & - & 1.89 \\
\hline
\end{tabular}


Table 4. External Factors Evaluation Matrix

\begin{tabular}{|c|c|c|c|c|}
\hline \multicolumn{2}{|c|}{ Factors } & \multicolumn{2}{|c|}{ Weight Grade } & Score \\
\hline 임 & 0:Zayandeh-rood river & 0.15 & 4 & 0.6 \\
\hline & $\mathrm{O}_{2}$ :The law of lacking industries within $50 \mathrm{~km}$ from the Esfahan city & 0.06 & 3 & 0.18 \\
\hline & $\mathrm{O}_{3}$ :The workshop-town of AmirKabir & 0.06 & 3 & 0.18 \\
\hline 韭 & urized irrigation technology & 0.03 & 3 & 0.09 \\
\hline$\overline{\bar{g}}$ & g plant pests & 0.03 & 3 & 0.09 \\
\hline & of Esfahan & 0.15 & 1 & 0.15 \\
\hline & & 0.13 & 1 & 0.13 \\
\hline F-1 & River over recent & 0.08 & 1 & 0.08 \\
\hline & $\mathrm{T}_{4}: \mathrm{Th}$ & 0.08 & 1 & 0.08 \\
\hline$\frac{\tilde{m}}{\mathrm{\omega}}$ & Nork in the city limits and boundaries & 0.1 & 1 & 0.1 \\
\hline & $\mathrm{T}_{6}:$ Th & 0.1 & 2 & 0.2 \\
\hline & $\mathrm{T}_{7}$ :Traditional met & 0.03 & 2 & 0.06 \\
\hline 100 & & 1 & - & 1.94 \\
\hline
\end{tabular}

The comparative analysis of the major internal and external factors using SWOT matrix and the Delphi method on the basis of brainstorming led to the following strategies for attaining the water-related green city goals of Esfahan city: aggressive strategies (utilization of recycled water in the irrigation of green spaces);conservative strategies (implementation of a comprehensive controlling system and under pressure irrigations of green spaces, supervision and regulation of industrial activities in the city, promotion of biological methods of controlling pests and optimizing the use of plant fertilizers, organizing illegal activities in the Zayandeh-Rood river bank and boundaries, consolidation of existing industrial areas and prevention of dispersed industries development) ;diversification strategies (the development and promotion of crop varieties resistant to dehydration, capacity utilization of streams in the disposal of surface waters); and defensive strategies (Using a proper method of cultivation and irrigation, improvement and modernization of drinking water distribution networks, developing and organizing sewage collection systems as well as improving south treatment plant, the cultivation of citizens' culture to change their water use patterns, restoring the old systems of water extraction, providing a balance between nutrition and water extraction from underground aquifers, the development and improvement of sewage treatment systems in city limits and boundaries, organizing open spaces in areas prone to feeding the aquifers)(Table 5).Simultaneous analysis of internal and external factors of Esfahan water supply using internal and external matrices also shows that the most appropriate strategies to achieve the green city goals of Esfahan for the water component are defensive. It should be noted that reduction, withdrawal, transfer, or liquidation strategies are also recommended according to the position of nine points in the matrix (Fig. 5).

Table 5. SWOT Matrix

\begin{tabular}{|c|c|}
\hline Aggressive Strategies & Conservative Strategies \\
\hline $\begin{array}{l}\text { SO1: Utilization of recycled sewage in the irrigation of } \\
\text { green spaces }\end{array}$ & $\begin{array}{l}\text { WO: Implementation of a comprehensive controlling system and scheduling } \\
\text { under pressured irrigations of green space } \\
\text { WO }_{2} \text { : Supervision and regulation of industrial activities in the city } \\
\mathrm{WO}_{3} \text { : Promotion of biological methods of controlling pests and optimizing the } \\
\text { use of plant fertilizers } \\
\mathrm{WO}_{4} \text { : Organizing illegal activities in the Zayandeh-rood river bank and } \\
\text { boundaries } \\
\mathrm{WO}_{5} \text { : The consolidation of existing industrial areas and prevention of dispersed } \\
\text { industries development }\end{array}$ \\
\hline Diversification Strategies & Defensive Strategies \\
\hline $\begin{array}{l}\mathbf{S T}_{1}: \text { The development and promotion of crop varieties } \\
\text { resistant to dehydration } \\
\mathrm{ST}_{2} \text { : The capacity utilization of streams in the disposal } \\
\text { of surface waters }\end{array}$ & $\begin{array}{l}\text { WT } \\
\text { WT } \text { :Using a proper method of cultivation and irrigation } \\
\text { WT }_{3} \text { : Developing and organizing sewage collection systems as well as } \\
\text { improving south treatment plant } \\
\text { WT }_{4} \text { : The cultivation of citizens' culture to change their water use patterns } \\
\text { WT }_{5} \text { : Restoring the old systems of water extraction } \\
\text { WT }_{6} \text { : Providing a balance between nutrition and water extraction from } \\
\text { underground aquifers } \\
\text { WT }_{7} \text { : The development and improvement of sewage treatment systems in city } \\
\text { limits and boundaries } \\
\text { WT }_{8} \text { : Organizing open spaces in areas prone to feeding the aquifers }\end{array}$ \\
\hline
\end{tabular}




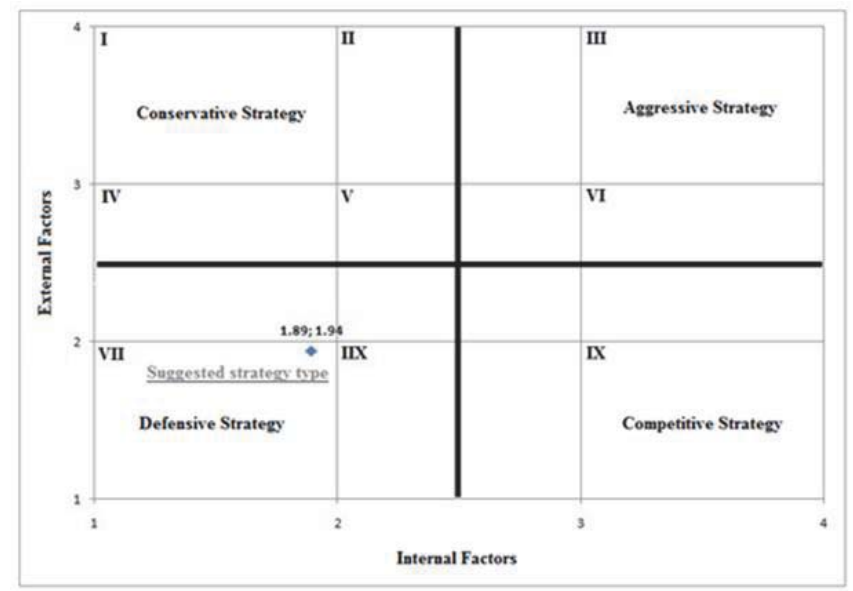

Figure 5. Internal and External Matrix

Prioritization of strategies for attaining the water-related green city goals of Esfahan using a QSPM matrix and expert opinions suggests that balancing the nutrition and extraction of water from underground aquifers is recommended as the most appropriate strategy (Table 6). It should be noted that in this study, strategies were divided into first to third priorities using the mean and standard deviation of the final results of the internal and external factors.

1. $\mathrm{WT}_{6}-\mathrm{WT}_{1}-\mathrm{WT}_{2}-\mathrm{WO}_{1}-\mathrm{WT}_{4}-\mathrm{WT}_{5}-\mathrm{SO}_{1}-\mathrm{ST}_{1}$

2. $\mathrm{WO}_{2}-\mathrm{WO}_{4}-\mathrm{WO}_{3}$

3. $\mathrm{WT}_{8}-\mathrm{ST}_{2}-\mathrm{WT}_{3}-\mathrm{WO}_{5}-\mathrm{WT}_{7}$

Table 6. QSPM Matrix

\begin{tabular}{|c|c|c|c|c|c|c|c|c|c|c|c|c|c|c|c|c|c|}
\hline actors & ah & 0 & & $\mathrm{WO}_{1}$ & & $\mathrm{WO}_{2}$ & & $\mathrm{WO}_{3}$ & & $\mathrm{WO}_{4}$ & & $\mathrm{WO}_{5}$ & $\mathrm{~S}$ & & & $\mathrm{ST}_{2}$ & \\
\hline & & $A$ & B & A & B & $\bar{A}$ & $B$ & $\mathbf{A}$ & B & $A$ & B & $A$ & B & A & B & $\mathrm{A}$ & B \\
\hline${ }_{1} \mathrm{O}$ & 0.15 & 1 & 0.15 & 2 & 0.3 & 2 & 0.3 & 2 & 0.3 & 3 & 0.45 & 1 & 0.15 & & 0.3 & & 0.15 \\
\hline${ }_{2} \mathrm{O}$ & & 1 & 06 & 1 & 0.06 & 4 & 0.24 & 1 & 0.06 & 2 & 12 & & & & 0.06 & & .06 \\
\hline${ }_{3} \mathrm{O}$ & & 1 & & 1 & & 3 & & 1 & & 3 & & 3 & & & & & \\
\hline${ }_{4} \mathrm{O}$ & & 3 & 0.09 & 4 & 0.1 & 1 & 0.03 & 1 & 0.03 & 1 & 0.03 & 1 & 03 & & .06 & 1 & .03 \\
\hline${ }_{5} \mathrm{O}$ & & 1 & 0.03 & 1 & 0. & 1 & & 4 & 0 & 1 & 0.03 & & & & 0.0 & & .03 \\
\hline${ }_{1} T$ & & 2 & 0. & 2 & & 1 & & 1 & & 1 & & & & & & & .15 \\
\hline${ }_{2 T} T$ & & 2 & 0.26 & 2 & 0.2 & 1 & 0.13 & 1 & 3 & 1 & 0.1 & & & &.$\angle 0$ & & 13 \\
\hline T & & 2 & 0.16 & 2 & 0. & 1 & 0 & 1 & & 1 & 08 & & & & 0.1 & & .08 \\
\hline${ }_{4} \mathrm{~T}$ & & 2 & 0.16 & 2 & 0.1 & 1 & 0.08 & 1 & 0.6 & 1 & 0.6 & & & & 0.16 & & 0.08 \\
\hline${ }_{5} \mathrm{~T}$ & & 1 & 0.1 & 1 & 0.1 & 2 & 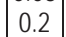 & 2 & 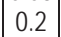 & 2 & 0.2 & & & & 0.1 & & 0.2 \\
\hline${ }_{6} \mathrm{~T}$ & & 1 & 0. & 1 & & 1 & & 1 & & 2 & & & & & & & 0.2 \\
\hline${ }_{7} \mathrm{~T}$ & & 2 & 0.06 & 3 & U. & 1 & 0. & 2 & & 1 & 0.03 & & & & .06 & & 0.03 \\
\hline$S_{1}$ & & 1 & 0.12 & 2 & 0.2 & 1 & 0.2 & 1 & 0.24 & 1 & 0.12 & & .12 & & .24 & & 0.48 \\
\hline $\mathrm{S}_{2}$ & & 4 & 0.24 & 1 & 0.0 & 2 & 0.0 & 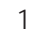 & & 1 & 0.0 & & & & 0.06 & & 0.12 \\
\hline $\mathrm{S}_{3}$ & & 2 & 0.0 & 2 & 0.0 & 1 & 0 & 1 & 8 & & 0. & & & & 0.16 & & 0.04 \\
\hline W & & 2 & 0.1 & 2 & 0.1 & 1 & 0. & 1 & & 2 & 0. & 1 & & & 0.1 & & 0.08 \\
\hline W & & 2 & 0.2 & 2 & 0.2 & 1 & 0. & 1 & 0. & 1 & 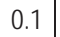 & 1 & & & 0.2 & & 0.1 \\
\hline$W_{3}$ & & 2 & 0.18 & 2 & 0.18 & 1 & 0.1 & 1 & 0. & 1 & 0.09 & & 9 & & 18 & & 0.09 \\
\hline$W_{4}$ & & & 0. & 1 & lo & 1 & & 1 & & & & 1 & & & & & ra \\
\hline W & & 2 & 0. & 2 & & 1 & & 1 & & 1 & 0. & & & & 0.1 & & 0.08 \\
\hline$W_{6}$ & & 1 & 0.04 & + & 0.04 & 1 & 0.04 & 1 & 0.04 & 1 & 0.04 & 1 & 0.04 & & 0.04 & & 0.16 \\
\hline W & & & 0.1 & 4 & 0. & 1 & o. & + & 0. & 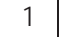 & J. & & & & 0 & & .04 \\
\hline W & & 2 & 0.12 & 1 & 0. & 2 & 0. & 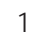 & o & 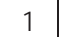 & 0.0 & 1 & & & 0.06 & 2 & 12 \\
\hline$W_{9}$ & & & .05 & & .05 & 4 & 0.05 & & 0.05 & 2 & 0.1 & & 0.1 & & 0.05 & & .05 \\
\hline
\end{tabular}




\begin{tabular}{|c|c|c|c|c|c|c|c|c|c|c|c|c|c|c|c|c|c|}
\hline $\mathrm{W}_{10}$ & .05 & 1 & .05 & 1 & 0.05 & 3 & 0.05 & 1 & 0.05 & 4 & 0.2 & 3 & \multicolumn{2}{|l|}{0.15} & 0.05 & 1 & .05 \\
\hline$W_{11}$ & .04 & 1 & 0.04 & 1 & 0.04 & 2 & 0.04 & 1 & 0.04 & 2 & 0.08 & 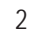 & \multicolumn{2}{|c|}{0.08} & .04 & & 0.04 \\
\hline$W_{12}$ & .04 & 1 & 0.04 & 1 & 0.04 & 1 & 0.04 & 4 & 0.04 & 1 & 0.04 & 1 & \multicolumn{2}{|l|}{0.04} & .04 & & .04 \\
\hline$W_{13}$ & .05 & 1 & 0.05 & 1 & 0.05 & 2 & 0.05 & 1 & 0.05 & 2 & 0.1 & 4 & \multicolumn{2}{|l|}{0.2} & .05 & & .05 \\
\hline Total & 2 & - & 3.28 & - & 3.37 & - & \begin{tabular}{|l|}
3.18 \\
\end{tabular} & - & 3 & - & 3.05 & - & \multicolumn{2}{|l|}{2.74} & 3.28 & & 2.8 \\
\hline \multirow[t]{2}{*}{ Factors } & \multirow{2}{*}{ Weight } & \multicolumn{2}{|c|}{$\mathrm{WT}_{1}$} & $\mathrm{WT}_{2}$ & \multicolumn{2}{|c|}{$\mathrm{WT}_{3}$} & \multicolumn{2}{|c|}{$\mathrm{WT}_{4}$} & \multicolumn{2}{|r|}{$\mathrm{WT}_{5}$} & \multicolumn{2}{|r|}{$\mathrm{WT}_{6}$} & \multicolumn{2}{|c|}{$\mathrm{WT}_{7}$} & \multicolumn{3}{|c|}{$\mathrm{WT}_{8}$} \\
\hline & & $A$ & B & A & B & A & B & A & B & $A$ & B & A & B & A & B & $A$ & B \\
\hline${ }_{1} \mathrm{O}$ & 0.15 & 2 & 0.3 & 2 & 0.3 & 2 & 0.3 & 2 & 0.3 & 2 & 0.3 & 2 & 0.3 & 2 & 0.3 & & 0.15 \\
\hline${ }_{2} \mathrm{O}$ & 0.06 & 1 & 0.06 & 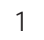 & 0.06 & 1 & 0.06 & 1 & 0.06 & 1 & 0.06 & 1 & 0.06 & 2 & 0.12 & & 0.06 \\
\hline${ }_{3} \mathrm{O}$ & 0.06 & 1 & 0.06 & 1 & 0.06 & + & 0.06 & 1 & 0.06 & 1 & 0.06 & 1 & .06 & 2 & .12 & & 0.06 \\
\hline${ }_{4} \mathrm{O}$ & 0.03 & 2 & 0.06 & 1 & 0.03 & 1 & 0.03 & 1 & 0.03 & 1 & 0.03 & 2 & 0.06 & 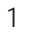 & 0.03 & & 0.03 \\
\hline${ }_{5} \mathrm{O}$ & 0.03 & 1 & 0.03 & 1 & 0.03 & 1 & 0.03 & 1 & 0.03 & 1 & 0.03 & 1 & .03 & 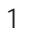 & .03 & & 0.03 \\
\hline${ }_{1} \mathrm{~T}$ & 0.15 & 0 & 0.3 & ? & 0.3 & 1 & 0.15 & 2 & 0.3 & 2 & 0.3 & 2 & 0.3 & 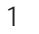 & .15 & & 0.3 \\
\hline${ }_{2} \mathrm{~T}$ & 0.13 & 2 & 0.26 & 2 & 0.26 & 1 & 0.13 & 2 & 0.26 & 2 & 0.26 & 2 & 0.26 & 1 & 0.13 & & 0.26 \\
\hline${ }_{3} \mathrm{~T}$ & 0.08 & 2 & 0.16 & 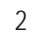 & 0.16 & 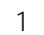 & 0.08 & 2 & 0.16 & 2 & 0.16 & & 16 & 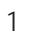 & .08 & & .08 \\
\hline${ }_{4} \mathrm{~T}$ & 0.08 & 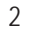 & 0.16 & 2 & 0.16 & 1 & 0.08 & 2 & 0.16 & 2 & 0.16 & $\angle$ & 0.16 & . & 0.08 & & 0.16 \\
\hline${ }_{5} \mathrm{~T}$ & 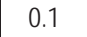 & 0 & 0.2 & 2 & 0.2 & 2 & 0.2 & 3 & 0.3 & 1 & 0.1 & 2 & 0.2 & 2 & 0.2 & & 0.2 \\
\hline${ }_{6} \mathrm{~T}$ & 1 & 1 & 0.1 & 2 & 0.2 & 2 & 0.2 & 1 & 0.1 & 1 & 0.1 & 3 & 0.3 & 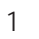 & 0.1 & & 0.3 \\
\hline${ }_{7} \mathrm{~T}$ & 0.03 & 4 & 0.12 & 1 & 0.03 & 1 & 0.03 & 1 & 0.03 & 2 & 0.06 & 2 & 0.06 & 1 & 0.03 & & 0.03 \\
\hline $\mathrm{S}_{1}$ & 0.12 & 1 & 0.48 & 1 & 0.12 & 1 & 0.12 & 1 & 0.12 & 2 & 0.24 & 2 & 0.24 & 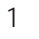 & 0.12 & & 0.12 \\
\hline $\mathrm{S}_{2}$ & 0.06 & 1 & 0.12 & 1 & 0.06 & 4 & 0.24 & 1 & 0.06 & 1 & 0.06 & 1 & 06 & 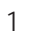 & .06 & & 0.06 \\
\hline $\mathrm{S}_{3}$ & 04 & 2 & 0.04 & 1 & 0.04 & 1 & 0.04 & 1 & 0.04 & 1 & 0.04 & 1 & 0.04 & 1 & 0.04 & & 0.04 \\
\hline$W_{1}$ & 0.08 & 0 & 0.08 & 2 & 0.16 & 1 & 0.08 & 2 & 0.16 & 2 & 0.16 & 2 & 0.16 & 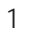 & 0.08 & & 0.08 \\
\hline$W_{2}$ & & 2 & 0.1 & 2 & 0.2 & 1 & 0.1 & 2 & 0.2 & 4 & 0.4 & 2 & 0.2 & 1 & 0.1 & & 0.1 \\
\hline$W_{3}$ & 09 & 1 & 0.09 & 3 & 0.27 & 2 & 0.18 & 4 & 0.36 & 1 & 0.09 & 1 & 0.09 & 1 & .09 & & 0.09 \\
\hline$W_{4}$ & & 1 & 0.06 & 4 & 0.24 & 1 & 0.06 & 1 & 0.06 & 1 & 0.06 & 1 & 6 & 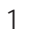 & 0.06 & & 0.06 \\
\hline$W_{5}$ & 8 & 2 & 0.08 & 2 & 0.16 & 1 & 0.08 & 2 & 0.16 & 3 & 0.24 & 2 & 0.16 & 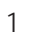 & 0.08 & & 0.08 \\
\hline$W_{6}$ & & 1 & 0.16 & 1 & 0.04 & 1 & 0.04 & 1 & 0.04 & 2 & 0.08 & 4 & 0.16 & 1 & 0.04 & & 0.16 \\
\hline$W_{7}$ & & 0 & 0.04 & 1 & 0.04 & 1 & 0.04 & 1 & 0.04 & 1 & 0.04 & 1 & 4 & 1 & 0.04 & & 0.04 \\
\hline$W_{8}$ & & $\perp$ & 0.12 & 1 & 0.06 & 4 & 0.24 & 1 & 0.06 & 1 & 0.06 & 1 & 0.06 & 1 & 0.06 & & 0.06 \\
\hline$W_{9}$ & 5 & 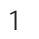 & 0.05 & 1 & 0.05 & 1 & 0.05 & 1 & 0.05 & 1 & 0.05 & 1 & 0.05 & 2 & 0. & & 0.1 \\
\hline$W_{10}$ & 0.05 & 1 & 0.05 & 1 & 0.05 & 1 & 0.05 & 1 & 0.05 & 1 & 0.05 & 1 & 0.05 & 2 & 0.1 & & 0.1 \\
\hline$W_{11}$ & 0.04 & 1 & 0.04 & 1 & 0.04 & 1 & 0.04 & 1 & 0.04 & 1 & 0.04 & 1 & 0.04 & 4 & 0.16 & & 0.04 \\
\hline$W_{12}$ & 0.04 & 1 & 0.04 & 1 & 0.04 & 1 & 0.04 & 1 & 0.04 & 1 & 0.04 & 1 & 0.04 & 1 & 0.04 & & 0.04 \\
\hline$W_{13}$ & 0.05 & 1 & 0.05 & 1 & 0.05 & 1 & 0.05 & 1 & 0.05 & 1 & 0.05 & 1 & 0.05 & 3 & 0.15 & 1 & 0.05 \\
\hline Total & 2 & - & 3.41 & - & 3.41 & - & 2.8 & $=$ & 3.32 & - & 3.32 & - & 3.45 & - & 2.69 & - & 2.88 \\
\hline
\end{tabular}

A: Attractiveness score

B: Sum of attractiveness scores

\section{Conclusion}

Results of the present study (which was aimed to study the environmental condition of Esfahan Metropolis within the framework of the green city approach with regard to its water) suggest that the water component of Esfahan Metropolis was in its most unstable state during the study period based on the green city indicators because the level of water in this city declined by $33.96 \%$ in 2009 as compared to 2008. However, the aforementioned trend was reversed from 2010 to 2011 and as a result the level of water in Esfahan Metropolis was increased by 45.71\% in 2011 as compared to 2009. In 2012, the qualitative and quantitative conditions of water in Esfahan Metropolis decreased for $1.96 \%$ as compared to 2011. Analysis of the external and internal factors contributing to the progress of the water component of Esfahan Metropolis also indicated that the weaknesses dominate the strengths and the threats dominate the chances. However, other factors (such as hygiene conditions, dredging and covering the body of rivers, increased extraction of water from surface and groundwater resources, increased dissipation of water in the water distribution network, reduced improvement of the industrial sewage treatment system, and river water quality) had the highest effect on the environmental changes in Esfahan Metropolis within the framework of green city approach during the study area. Therefore, it is recommended to adopt defensive strategies to implement the strategic plan for attainment of the water goals in the Esfahan Green Metropolis project. The first priority of these strategies should include the following tasks: Providing a balance between nutrition and water extraction from underground aquifers; application of a proper cultivation and irrigation model; improvement and modernization of the drinking water distribution network; cultivation of citizens' 
culture to change their water use patterns; and restoring the old systems of water extraction. The second priority of these strategies should include the following tasks: organization of open spaces in areas prone to feeding the aquifers; development and organization of the sewage collection systems; improving the southern treatment plant; and development and improvement of the wastewater treatment system of industries within the boundaries of Esfahan Metropolis.

\section{References}

Abdullatif, S., Bidin, Y.H. and Z. AWANG. (2013). Towards the Realization of Green Cities: The Moderating Role of the Residents' Education Level. Procedia-Social and Behavioral Sciences, 85: 646-652.

Abubakar, A.H. and K.S. Chen. (2013). A Framework for Assessing the Sustainable Urban Development. Procedia-Social and Behavioral Sciences, 85: 484-492.

Bai, X. and J. TANG. (2010). Ecological Security Assessment of Tianjin by PSR Model. Procedia Environmental Sciences, 2:881-887.

Bahramsoltani, K. (2008). Environment. 2nd ed., Urban Planning and Architecture Research Center of Iran Publishing, 323 Pages.

Cohen, N. and P. Robbins. (2011). Green Cities: An A to Z Guide, 1st ed.; SAGE Publishing, 576 Pages.

Dempsey, N., Brown, C. and G. Bramley. (2012). The Key to Sustainable Urban Development in UK Cities?: The Influence of Density on Social Sustainability, 1st ed.; Elsevier Publishing, 141 Pages.

Dai, J., et al. (2010). Integrated Water Resource Security Evaluation of Beijing Based on GRA and TOPSIS. Frontiers of Earth Science, 4(3): 375-362.

Economist Intelligence Unit. (2011). African Green City Index.

Economist Intelligence Unit. (2011). Asian Green City Index.

Economist Intelligence Unit. (2011). US and Canada Green City Index.

Economist Intelligence Unit. (2010). Latin American Green City Index.

Economist Intelligence Unit. (2010). European Green City Index.

FEATHERSTONE, J., et al. (2011). Creating a Sustainable City: Philadelphia's Green City Clean Waters Program. 47th ISOCARP Congress.

Guo, T.Z., Xue, X.F. and R. LI. (2008). Application of TOPSIS in Environmental Quality Assessment of Huafei River in Kaifeng. Meteorological and Environmental Sciences. 31(2):59-62.

Hughey, K.F., et al. (2004). Application of the Pressure- State- Response Framework to Perceptions Reporting of the State of the New Zealand Environment. Journal of Environmental Management, 70(1): 85-93.

Hwang, C.L. and K.S. Yoon. (1981). Multiple Attribute Decision Making: Methods and Applications. Springer- Verlag Berlin Heidelberg.

Jozi, S.A., et al. (2012). An Integrated Shannon's Entropy-TOPSIS Methodology for Environmental Risk Assessment of Helleh Protected Area in Iran, Environmental Monitoring and Assessment, 184(11): 6913-6922.

Kahn, M.E. (2006). Green cities: Urban Growth and the Environment, 1st ed.; Brookings Institution Publishing, 160 Pages.

Kaufmann, A. and M. GUPTA. (1988). Fuzzy Mathematical Models in Engineering and Management Science, 1st ed.; Elsevier Publishing, 337 Pages.

Liu, H., et al. 2014. Analysis of Sustainable Urban Development Approaches in China. Habitat International, 41:24-32.

Li, P., WU, J. and H. QIAN. (2012). Groundwater Quality Assessment Based on Rough Sets Attribute Reduction and TOPSIS Method in a Semi-arid Area, China. Environmental Monitoring and Assessment, 184(8): 4841-4854.

New South Wales Department of Planning. (2005). City of Cities: a Plan for Sydney's Future.

National Sanitation Foundation. 1970. Water Quality Index.

NAVABAKHSH, M. and A. Tavakolan. (2013). Strategic Planning to Organize the Urban Historic Fabric Emphasizing on the Environmental Concerns. Int. J. Environ. Res, 7(3): 523-532.

Organization for Economic Co-operation and Development. (1994). Environmental Indicators. PASADENA Planning Department. (2010) .Green City Indicators Report.

Pasadena Planning Department. (2006). Green City Action Plan.

Pugh, S. (2001). Sustainable Cities in Developing Countries, 1st ed.;Routledge Publishing, 265 Pages.

Song, U. (2011). Ecological City and Urban Sustainable Development. Procedia Engineering, 21:142-146.

Sanusi, Y.A. (2011). Pressure-State-Response Framework Analysis of Residential Development on Ecologically Unstable Land in Minna, Nigeria. Ozean Journal of Applied Sciences, 4(2):145-169.

Sydney City Council. (2008). Sustainable Sydney 2030: City of Sydney Strategic Plan.

Shiehbeiki, SH., et al. (2014). Public Participation Role on Sustainable Urban Management by Quantitative Strategic Planning Matrix (QSPM). Int. J. Environ. Res, 8(4): 1309-1314.

Turner, M. 2008. Review of Green Cities. Regional Science and Urban Economics, 38(4): 404-405.

Tehrani, S.M., et al. (2010). Role of E-Shopping Management Strategy in Urban Environment. Int. J. Environ. Res, 4(4): 681 - 690.

Wang, Q., et al. (2013). Key Evaluation Framework for the Impacts of Urbanization on Air Environment, Ecological Indicators, 24:266272.

World Health Organization. (2011). Guidelines for Drinking Water Quality.

Wu, H.J. 2009. The Way Toward Green City - the Case of Shenzhen. 45 th ISOCARP Congress. 
Warsaw City Council. (2005). Development Strategy for the City of Warsaw until 2020.

Yalcin, G. (2014). Urban Activities in the View of the Sustainable Development. Procedia Technology, 12: 566-571.

Yavuz, F. and T. Baycan. (2013). Use of SWOT and Analytic Hierarchy Process Integration as a Participatory Decision Making Tool in Watershed Management. Procedia Technology, 8:134-143.

Zhang, X.C., et al. (2012). Evaluation and Simulation for Ecological Risk Based on Energy Analysis and Pressure - State - Response Model in a Coastal City, China. Procedia Environment Sciences, 13:221-231. 